Management Theory and Studies for Rural Business and Infrastructure Development

eISSN 2345-0355. 2021. Vol. 43. No. 4: 517-523

Article DOI: https://doi.org/10.15544/mts.2021.46

\title{
EDUCATIONAL COMPETENCIES OF SPECIALISTS WORKING IN YOUTH ORGANIZATIONS IN RURAL AREAS
}

\author{
Iryna Snovydovych ${ }^{1}$, Nataliia Danylevych ${ }^{2}$, Liubov Drozdovska ${ }^{3}$ Mariia Kvak ${ }^{4}$ Bohdan \\ Kopylchak $^{5}$
}

${ }^{1}$ Postgraduated student, Ivan Franko National University of Lviv. Universytetska str. 1. 79000. Lviv. Ukraine. Phone No.: +380962541222. E-mail address: iryna.snovydovych@lnu.edu.ua

${ }^{2}$ Associate Prof., Ivan Franko National University of Lviv. Universytetska str. 1. 79000. Lviv. Ukraine. Phone No.: +380638083699. E-mail address: danylevychnatali@gmail.com

${ }^{3}$ Postgraduated student, Ivan Franko National University of Lviv. Universytetska str. 1. 79000. Lviv. Ukraine. Phone No.: +380673669681. E-mail address: lyubov.drozdovska@lnu.edu.ua

${ }^{4}$ Associate Prof., Ivan Franko National University of Lviv. Universytetska str. 1. 79000. Lviv. Ukraine. Phone No.: +380676644212.E-mail address: mariya.kvak@lnu.edu.ua

${ }^{5}$ Postgraduated student, Ivan Franko National University of Lviv. Universytetska str. 1. 79000. Lviv. Ukraine. Phone No.: +380638202399. E-mail address: kopul.chak@gmail.com

Received 0607 2021; Accepted 05082021

\begin{abstract}
Modern problems of work with youth in rural areas determine the necessity of identification of educational competencies of specialists working in youth organizations, which determines the directions in life of young people. The purpose of the article is to study the most important educational competencies of specialists working in youth organizations in rural areas, based on the analysis of the impact of educational competencies of specialists on the directions in life for youth. Educational competencies of youth work include both general ethical competencies and specific professional competencies related to youth work. The study has been conducted in 2016 and 2021 to compare changes in educational competencies. The structural equation modeling to solve the problem of identifying the relationships between ethical and professional competencies, and the directions in life for youth, and sociological survey to identify the specific area of interest of young people living in rural areas was used.
\end{abstract}

Keywords: educational competencies, ethical and professional competencies, rural areas, youth organizations. JEL Codes: I21, J13, L31, R50, Z13.

\section{Introduction}

At the present stage of social and economic transformations, the position of young people is very vulnerable in all vital areas, including in terms of the current income and housing. Youth work is designed to develop a youth activity in rural areas, to provide young people with the opportunity to gain experience and to achieve life's goals. Our country needs responsible training of such specialists who are capable and ready to introduce into practice professional tools for working with young people in a crisis and difficult life situations. The work of youth organizations in rural areas covers a wide range of services depending on the needs and interests of young people. Youth organizations are designed to provide opportunities for young people living in rural areas; for young people facing difficult life circumstances (housing problems, psychological and physical health problems, employment problems, etc.); for young people belonging to certain groups or communities (for an example, young people

Copyright (C) 2021 Author(s), published by Vytautas Magnus University. This is an open access article distributed under the terms of the Creative Commons Attribution Non-Commercial 4.0 (CC BY-NC 4.0) license, which permits unrestricted use, distribution, and reproduction in any medium provided the original author and source are credited. The material cannot be used for commercial purposes. 
with disabilities, ethnic groups, etc.). These services have a significant impact on the lives of young people in rural areas.

The formation of educational competencies of specialists working in youth organizations in rural areas is the key to the successful work with youth. Such competencies are specific and unique individual's characteristics (Yurynets, Snovydovych, 2020).

Specialists working in youth organizations should have:

- the skills to build relationships with young people and community groups;

- the learning and teaching practices;

- the knowledge about the peculiarities of adolescent and youth development, and ensuring the appropriate support;

- the knowledge about how to manage a youth's defiant behavior and the de-escalation of the conflict;

- the skills to build a trusting relationship with youth and to encourage young people's voluntary participation;

- the skills to protect young people and to create a safe environment for them.

Therefore, much attention is paid to the educational competencies of youth workers (specialists) to work in youth organizations in rural areas with the aim of improving the quality of youth work activities. Educational competencies of youth work include both general ethical competencies and specific professional competencies related to youth work.

The purpose of the article is to study the most important educational competencies of specialists working in youth organizations in rural areas, based on the analysis of the impact of educational competencies of specialists on the directions in life for youth.

The study was analyzed ethical and professional educational competencies that should be possessed by specialists to work in youth organizations in rural areas. A study was carried out in order to compare the change in educational competencies over the time.

The object of the study is the specialists working in youth organizations in rural areas.

The subject of the study is the educational competencies of specialists working in youth organizations in rural areas, and the impact of the most important educational competencies on the directions in life for young people.

\section{Proposed methodology}

The study is based on the following methods: systematization and generalization to clarify the educational competencies influencing the directions in life for young people; induction and deduction, generalization and comparison in the study of the characteristics of educational competencies of specialists working in youth organizations in rural areas and its main components; synthesis and analysis to justify the need for the impact of educational competencies of specialists on the directions in life for youth; structural equation modeling to solve the problem of identifying the relationships between ethical and professional competencies, and the directions in life for youth; sociological survey to identify the specific area of enormous interest of young people living in rural areas; schematic and graphic images for the visual representation of the results of research and analytical data.

Thanks to the method of sociological survey, we analyzed the opinions of young people on the problems of living in rural areas, support of youth by specialists working in youth organizations. The current study utilized a youth survey based on the questionnaire.

The survey for young people between 16 and 25 years of age in rural areas across Ukraine was conducted. The study has been conducted in 2016 and 2021 to compare changes in educational competencies. The members were invited to fill an 18-item survey. The Statistical Package for the Social Sciences was used to obtain the results.

The following educational competencies were selected for the study:

- The professional competencies of a specialist (PK) for work in youth organizations in rural areas include as follows: care and assistance of young people (CS); success in addressing the challenges of youth development (SA); training skills for youth work (TS). 
- The ethical competencies of a specialist (EK) for work in youth organizations in rural areas include as follows: treating young people with respect (TR); zero tolerance to violence and discrimination $(\mathrm{ZV})$; conducive to the realization of the right of young people to make their own decisions (RR).

The directions in life for youth living in rural areas (DL) include as follows: general sense of well-being of young people (WB), aspiration to self-realization (SR) and selfmotivation (SM).

\section{Literature review}

Scientists draw attention to the formation of the key educational competencies of specialists, which create organizational and pedagogical conditions for the implementation of practical training of young people (Schneckenberg, Wildt, 2006; Davidson, Wien, Anderson, 2010; Chouhan, 2014). The formation of educational competencies is an important task of all developed countries. Zulfikarova, Jabbarova (2020) analyze the reforms in the area of education, and information on the development of young people as mature individuals.

Witt, Caldwell (2018) review the creation of a distinct period between childhood and adult status that was labeled "adolescence," and the subsequent development of youth serving organizations to serve the developmental needs of a group of young people. Sirenko, Lunkina, Burkovska, Mikulyak, Gannichenko (2020) consider the integration of young people living in rural areas into society. It is justified that on the basis of educational competencies, a close interrelationship with the degree of development of the future specialist's personality is created. The authors (Curran, Bowness, Comack, 2010).

Taru, Krzaklewska, Basarab (2020) point to the importance of forming ethical and professional competencies of specialists working in youth organizations. Kieu, Singer (2020) analyze of each youth organization's strength and weaknesses, and youth' demands.
The authors suggest steps to improve youth organization activity, including forming ethical and professional competencies, fostering leadership, setting up a relationship, and creating a communication network.

$$
\text { In the scientific literature }
$$

(Schneckenberg, Wildt, 2006; Odontsova, Oslon, Ogol, 2019), much attention is paid to the problem of the formation of ethical and professional competencies of young workers to solve the problems of building positive relationships with marginalized youth. With the change in the functions and powers of youth organizations, there is a need for preparation and retraining of specialists, the development of their ethical and professional competence. The most important condition for integration of young people living in rural areas into society is the allocation of those ethical and professional competencies that are necessary for specialists to implement the new goals of education. An important stage is the diagnostics of the development of significant ethical and professional competencies through questionnaires, economic and mathematical modeling or other appropriate methods (Green, Davis, 2015; Yurynets, Yurynets, Denysenko, Myshchyshyn, Pekhnyk, 2021).

While we commend the scientific and research contribution of top researchers, it must be pointed out that the problem of formation of educational competencies of specialists working with youth in rural areas is especially relevant.

\section{Study results}

352 young people who are in contact with specialists in youth organizations in rural areas across Ukraine took part in the survey. $46 \%$ of respondents were male and $54 \%$ of respondents were female.

Initial data were assessed in accordance with the criteria (skewness, outliers, kurtosis, missing values). The sample size was big enough. The values for research were within the permissible range, and normally distributed. The results of the survey were processed by factor analysis. 
The structural equation modeling was used to solve the task. This technique is the combination of factor analysis and multiple regression analysis, and it is used to analyze the structural relationship between measured variables and constructs (Schreiber, 2008).
The below table displays the calculations of the main indicators of factor and regression analysis.

Table 1. The main indicators of factor analysis

\begin{tabular}{|l|l|}
\hline Statistics & Values \\
\hline Respondents (number of young people) & 352 \\
\hline CFI (Comparative fit index) & 0,906 \\
\hline Chi-squared (P-value) & 0,000 \\
\hline RMSEA (Root mean square error of approximation) & 0,121 \\
\hline SRMR (Standardized Root Mean Square Residual) & 0,109 \\
\hline TLI (Tucker-Lewis index) & 0,878 \\
\hline
\end{tabular}

The main indicators demonstrate the correctness of modeling and a good fit of the developed model to the received data.

The study has been conducted in 2016 and 2021 to compare changes in educational competencies.
The table below shows the results associated with the influence of educational competencies (ethical and professional competencies) of specialists on the directions in life of young people in 2016.

Table 2. The influence of educational competencies of specialists on the directions in life of young people in 2016

\begin{tabular}{|l|l|l|l|l|l|l|}
\hline $\begin{array}{l}\text { Types of } \\
\text { educational } \\
\text { competencies }\end{array}$ & $\begin{array}{l}\text { Variable } \\
\text { (educational } \\
\text { competencies) }\end{array}$ & $\begin{array}{l}\text { Estimate } \\
\text { of beta }(\boldsymbol{\beta})\end{array}$ & $\begin{array}{l}\text { Standard } \\
\text { error }\end{array}$ & $\begin{array}{l}\text { Standard } \\
\text { score (z) }\end{array}$ & P-value & $\begin{array}{l}\text { Standardized } \\
\text { relevant } \\
\text { coefficient }\end{array}$ \\
\hline PK & CS & $-0,742$ & 0,031 & $-28,450$ & 0,000 & $-0,811$ \\
\hline PK & SA & $-0,719$ & 0,029 & $-21,935$ & 0,000 & $-0,763$ \\
\hline PK & TS & 0,302 & 0,032 & 10,727 & 0,000 & 0,320 \\
\hline EK & TR & 1,343 & 0,028 & 41,724 & 0,000 & 0,901 \\
\hline EK & ZV & 1,278 & 0,027 & 43,172 & 0,000 & 0,878 \\
\hline EK & RR & 0,937 & 0,026 & 36,029 & 0,000 & 0,732 \\
\hline DL & 0,653 & 0,035 & 20,271 & 0,000 & 0,710 \\
\hline DL & WB & 0,457 & 0,033 & 11,194 & 0,000 & 0,327 \\
\hline DL & SR & 0,525 & 0,032 & 18,306 & 0,000 & 0,626 \\
\hline Regression analysis & SM & $-0,237$ & 0,031 & $-6,057$ & 0,000 & $-0,201$ \\
\hline DL & PK & 0,682 & 0,032 & 21,263 & 0,000 & 0,592 \\
\hline DL & EK & & & & \\
\hline
\end{tabular}

An important task is to obtain standardized relevant coefficient.

In 2016, the ethical competencies (EK) of a specialist to work in youth organizations in rural areas have the greatest impact on the formation and choice of the directions in life (DL) for youth $(0,592)$ (see Table 2). The professional competencies (PK) have a smaller influence on the directions in life for youth (0,201).
All selected ethical competencies are essential for young people living in rural areas. Treating young people with respect (TR) is the most important competence in the opinion of young people $(0,901)$.

A young people gave the negative rating to care and assistance of young people (CS) (0,811 ) and success in addressing the challenges of youth development (SA) ($0,763)$. 
Management Theory and Studies for Rural Business and Infrastructure Development eISSN 2345-0355. 2021. Vol. 43. No. 4: 517-523

Article DOI: https://doi.org/10.15544/mts.2021.46

The general sense of well-being of young people (WB) was more significant for young people (0,710). The aspiration to selfrealization (SR) was less important for young people $(0,327)$.
Table 3 shows the results associated with the influence of educational competencies of specialists for work in youth organizations in rural areas on the directions in life of young people in 2021.

Table 3. The influence of educational competencies of a specialists on the directions in life of young people in 2021

\begin{tabular}{|l|l|l|l|l|l|l|}
\hline $\begin{array}{l}\text { Types of } \\
\text { educational } \\
\text { competencies }\end{array}$ & $\begin{array}{l}\text { Variable } \\
\text { (educational } \\
\text { competencies) }\end{array}$ & $\begin{array}{l}\text { Estimate } \\
\text { of beta ( }(\boldsymbol{\beta})\end{array}$ & $\begin{array}{l}\text { Standard } \\
\text { error }\end{array}$ & $\begin{array}{l}\text { Standard } \\
\text { score (z) }\end{array}$ & $\begin{array}{l}\text { P- } \\
\text { value }\end{array}$ & $\begin{array}{l}\text { Standardized } \\
\text { relevant } \\
\text { coefficient }\end{array}$ \\
\hline PK & CS & $-0,719$ & 0,033 & $-27,294$ & 0,000 & $-0,798$ \\
\hline PK & SA & $-0,672$ & 0,031 & $-22,837$ & 0,000 & $-0,771$ \\
\hline PK & TS & 0,249 & 0,031 & 10,174 & 0,000 & 0,313 \\
\hline EK & TR & 1,284 & 0,027 & 40,385 & 0,000 & 0,892 \\
\hline EK & ZV & 1,186 & 0,028 & 42,836 & 0,000 & 0,846 \\
\hline EK & RR & 0,837 & 0,027 & 35,193 & 0,000 & 0,701 \\
\hline DL & WB & 0,784 & 0,035 & 21,107 & 0,000 & 0,788 \\
\hline DL & SR & 0,524 & 0,034 & 12,047 & 0,000 & 0,432 \\
\hline DL & SM & 0,591 & 0,033 & 18,979 & 0,000 & 0,697 \\
\hline Regression analysis & & & & & & \\
\hline DL & PK & $-0,253$ & 0,031 & $-5,284$ & 0,000 & $-0,237$ \\
\hline DL & EK & 0,472 & 0,034 & 19,527 & 0,000 & 0,524 \\
\hline
\end{tabular}

In 2021, the results revealed that the professional competencies (PK) have a negative influence on the directions in life for youth (DL) $(-0,237)$. A positive and considerable relation was discovered between directions in life for youth (DL) and the ethical competencies of a specialist (EK) $(0,524)$. Therefore, the commitment to high ethical standards has a positive impact on directions in life for youth (DL).

In 2021, a young people gave the negative review to care and assistance of young people (CS) $(-0,798)$ and success in addressing the challenges of youth development (SA) (-0,771) among professional competencies. The major role of training skills for youth work (TS), of all professional competencies at the reason of the general sense of well-being, aspiration to self- realization, and self-motivation of young people, is undeniable.

All chosen ethical competencies are substantial for young people living in rural areas. A young people mentioned the need for substantial increases in ethical competencies in this area.

The general sense of well-being of young people, aspiration to self-realization, and selfmotivation of young people continues to play a crucial role in the implementation of the directions in life of young people.

To determine differences, the standardized relevant coefficients for data in 2016 and 2021 were compared by identifying the factual differences. As a result, we had received a percentage of the final value obtained (Table 4). 
Table 4. Comparison of results of the impact of educational competencies of a specialists on the directions in life for youth in 2016 and 2021

\begin{tabular}{|l|l|l|l|l|l|}
\hline $\begin{array}{l}\text { Types of } \\
\text { educational } \\
\text { competencies }\end{array}$ & $\begin{array}{l}\text { Variable } \\
\text { (educational } \\
\text { competencies) }\end{array}$ & $\mathbf{2 0 2 1}$ & $\mathbf{2 0 1 6}$ & Difference & $\begin{array}{l}\text { Difference } \\
\text { in \% }\end{array}$ \\
\hline PK & CS & $-0,798$ & $-0,811$ & 0,013 & $-1,6$ \\
\hline PK & SA & $-0,771$ & $-0,763$ & $-0,008$ & 1,0 \\
\hline PK & TS & 0,313 & 0,320 & $-0,027$ & $-2,2$ \\
\hline EK & TR & 0,892 & 0,901 & $-0,009$ & $-1,0$ \\
\hline EK & ZV & 0,846 & 0,878 & $-0,032$ & $-3,8$ \\
\hline EK & RR & 0,701 & 0,732 & $-0,031$ & $-4,4$ \\
\hline DL & WB & 0,788 & 0,71 & 0,078 & 9,9 \\
\hline DL & SR & 0,432 & 0,327 & 0,105 & 24,3 \\
\hline DL & SM & 0,697 & 0,626 & 0,071 & 10,2 \\
\hline Regression analysis & PK & & & & \\
\hline DL & EK & $-0,237$ & $-0,201$ & $-0,036$ & 15,2 \\
\hline DL & 0,524 & 0,592 & $-0,068$ & $-13,0$ \\
\hline
\end{tabular}

Professional competencies of a specialist of youth organizations affect directions in life for youth in rural areas, which, in turn, affects the general sense of well-being of young people, aspiration to self-realization and selfmotivation. The study highlighted that directions in life for youth are driven by various educational competencies.

For young people (as compared to 2016), the professional competencies of a specialist make a bigger impact $(15,2 \%)$ on directions in life. The ethical competencies exert smaller influence on directions in life for youth ($13,0 \%)$.

Analysis of the resulting data found that the directions in life for youth are increasingly influenced by success in addressing the challenges of youth development (1\%). However, the directions in life are less influenced by conducive to the realization of the right of young people to make their own decisions $(-4,4 \%)$.

In 2021, the general sense of wellbeing of young people $(9,9 \%)$, aspiration to self-realization $(24,3 \%)$ and self-motivation $(10,2 \%)$ became more important for young people. The aspiration to self-realization (SR) has especially increased.

\section{Conclusions}

There are several findings associated with this research. First, specialists for work in youth organizations in rural settlements should be taught that ethical competencies substantively impact formation and choice of directions in life for youth living in rural areas. Treating young people with respect, zero tolerance to violence and discrimination, conducive to the realization of the right of young people to make their own decisions are essential for young people living in rural areas. Feedback from specialists for work in youth organizations in rural areas should be provided so that specialists develop an understanding of the manner in which the ethical competencies may elicit young people to build a future life.

A second result of a study finding is that the importance of the professional competencies of specialists for work in youth organizations in rural areas is gradually growing.

And thirdly, among professional competencies a special place is given to such educational competence of specialist as success in addressing the challenges of youth development. Among ethical competencies a special place is given to such competence by a specialist as treating young people with respect.

Further research is desired to better figure out the impact of professional and ethical competencies of specialists working in youth organizations in rural areas on directions in life for youth living in rural areas. 


\section{References}

Chouhan, J. (2014). The Significant Role of Youth and Community Development Work. International Critical Thought. No. 4(3): 389-395.

Curran, A., Bowness, E., Comack, E. (2010). Meeting the needs of youth: Perspectives from youth-serving agencies. - Winnipeg: Canadian Centre for Policy Alternatives, Manitoba. 124 p.

Davidson, J., Wien, S., Anderson, K. (2010). Creating a provincial family council to engage youth and families in child \& youth mental health systems. Journal of the Canadian Academy of Child \& Adolescent Psychiatry. No. 19: $169-175$.

Green, J.W., Davis, J.M. (2015). PYD and Professional Development of Youth Organizations. Journal of Youth Development. Vol. 10, No. 1. - https://doi.org/10.5195/jyd.2015.425

Kieu, K., Singer, J. (2020). Youth Organizations' Promotion of Education for Sustainable Development Competencies: A Case Study. European Journal of Sustainable Development. No. 9(4): $376 . \quad-$ https://doi.org/10.14207/ejsd.2020.v9n4p376

Odontsova, M.A., Oslon, V.N., Ogol, M.P. (2019). Self-activation as a basis for personal and professional competence development of specialists working with orphan adolescents. Psychology and Law. Vol. 9, No. 4: 1-17.

Schneckenberg, D., Wildt, J. (2006). Understanting the concept of competence for academic staff. - Germany: University of Dortmund. 56 p.

Schreiber, J. B. (2008). Core reporting practices in structural equation modeling. Research in Social \& Administrative Pharmacy. No. 4(2): 83-97.

Sirenko, N., Lunkina, T., Burkovska, A., Mikulyak, K., Gannichenko, T. (2020). The socialization of education as a means of developing entities within the agricultural sector. Management Theory and Studies for Rural Business and Infrastructure Development. Vol. 42, No. 4: 441-451.

Taru, M., Krzaklewska, E., Basarab, T. (2020). Youth worker education in Europe. Policies, structures, practices. - Budapest, Council of Europe and European Commission. 86 p. - https://pjpeu.coe.int/documents/42128013/47261623/Web-PREMS-051920-Education-of-youth-workers-in-

Europe.pdf/484a2b36-7784-d953-bfc4-2a34c988e854

Witt, P. A., Caldwell, L.L. (2018). Youth organizations then and now. Youth Development Principles and Practices in Out-of-School Time Settings. - Sagamore: Venture Publishing. 162 p.

Yurynets, R., Yurynets, Z., Denysenko, M., Myshchyshyn, I., Pekhnyk, A. (2021) The influence of educational competencies of the staff on the efficiency of hotel companies in the tourism sector. CEUR Workshop Proceedings, No. 2870: 1225-1237. - http://ceur-ws.org/Vol-2870/paper90.pdf

Yurynets, Z., Snovydovych, I. (2020). Development of higher education within the competence approach // Zarządzanie przedsiębiorstwem w dobie globalnych problemów, pod red. A. Piotrowska. Łódź: Wydawnictwo SIZ. 283295. - https://www.wydawnictwo-siz.pl/zarzadzanie-przedsiebiorstwem-w-dobie-globalnych-problemow/

Zulfikarova, Z., Jabbarova, D. (2020). Formation of modern, intellectually competent youth is a priority task. The American Journal of Social Science and Education Innovations. Vol. 02. No. 12: 382-385. 